Department of Animal Hygiene and Zoonoses,

Faculty of Veterinary Medicine,

Alexandria University.

\title{
DIAGNOSTIC VALUE OF PCR OF SALMONELLA ENTERICA SEROVAR ENTERITIDIS IN POULTRY AND HUMAN CONTACTS
}

(With 3 Tables and One Figure)

\author{
By

\section{H.A. SAMAHA and M.A. NOSSAIR}

(Received at 23/11/2011)

\section{القيمة التشخيصية لتفاعل البلمرة المتسلسل لميكروب السالمونيلا انتريتيدس

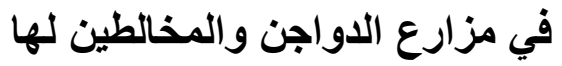 \\ حامل سعاحة ، محعد نصير}

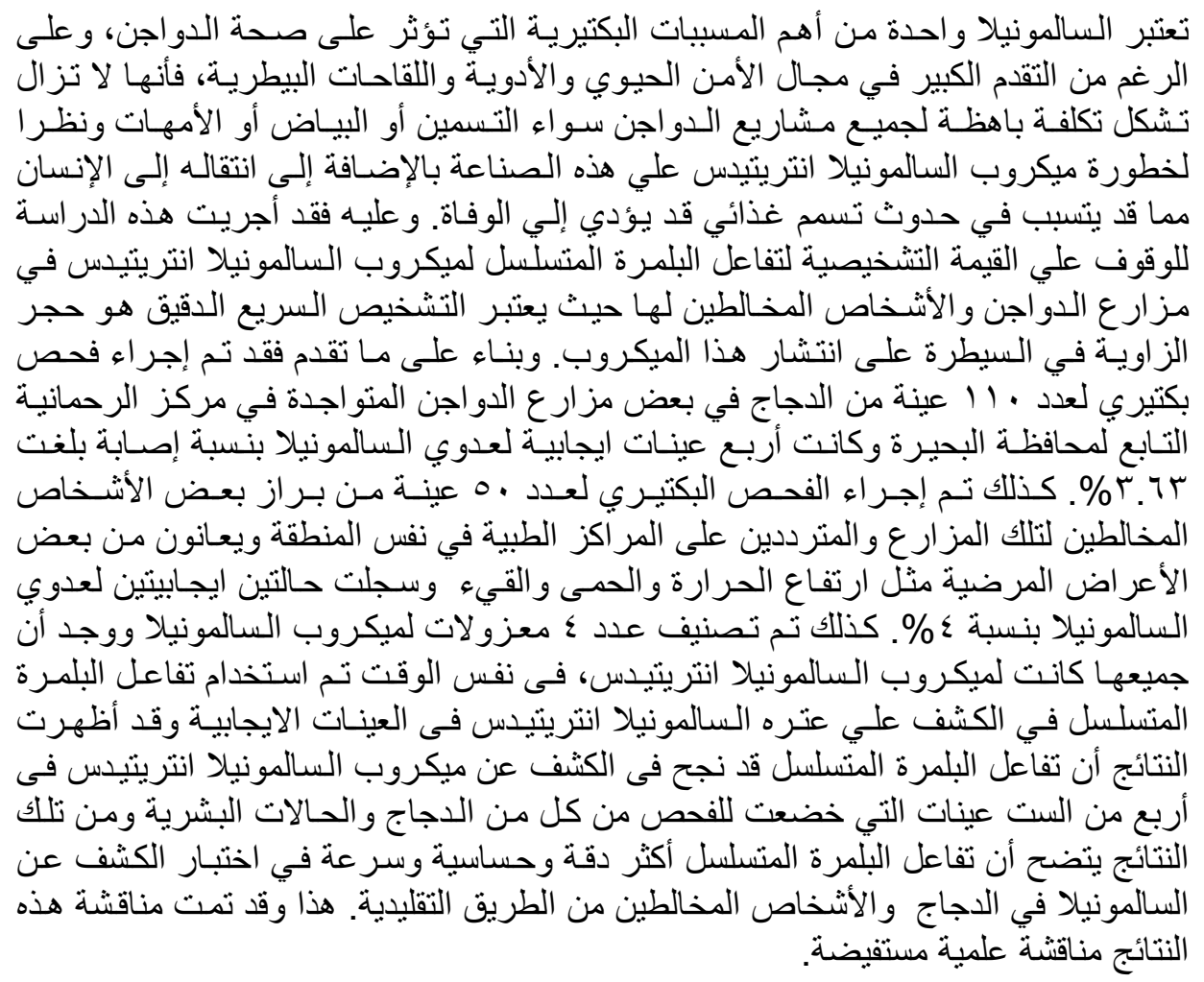




\section{SUMMARY}

A total of 110 chicken samples were collected randomly from naturally infected farms in Al-Rahmania district in Behera Province, Egypt where birds suffered from mottled liver with yellowish discoloration, distended gallbladder, slight air sacculitis, congested lungs and enlarged spleens. Liver, heart, spleen and cloacal swabs from chickens were sampled for isolation of Salmonella enterica serovar Enteritidis (SE). In addition, 50 human stool samples were collected from persons suffering from pyrexial illness with diarrhea and vomiting for several days hospitalized in areas surrounding examined poultry farms to be investigated for presence of SE by bacteriological examination. The obtained results of bacteriological examination revealed that Salmonella spp. were isolated from 4 out of $110(3.63 \%)$ of examined broiler chicken samples and 2 out of $50(4 \%)$ of examined stool samples. The serological identification of Salmonella isolates by using polyvalent and monovalent $(\mathrm{O})$ and $(\mathrm{H})$ Salmonella antisera clarified that 3 isolates from chicken isolates were proved to be SE and one isolate from human isolates was proved to be SE. At the same time, all positive samples were re-examined by using Polymerase chain reaction (PCR) where its result revealed that 4 isolates out of 6 were SE. The obtained results of the current work confirmed the diagnostic value of PCR detection of SE in poultry and surrounding people in which PCR is very sensitive, very specific and relatively rapid test.

Key words: Salmonella, Poultry, human, PCR.

\section{INTRODUCTION}

Poultry industry plays an important role in offering cheap source of animal protein for human beings in Egypt where prices of red meat, milk products and other sources of animal protein reached very high levels. Classification of Salmonella showed that there were more than 2300 serologically identified serotypes but only two serotypes were proved as true poultry pathogens named $S$. gallinarum and S. pullorum (Gast, 1997). On contrary, SE seldom caused disease symptoms in poultry but it was of major concern to public health since it was one from the commonest agents for human food poisoning as it could be transmitted either directly by contact between poultry men and infected birds or indirectly through consumption of poultry meat or egg or 
through contamination of poultry meat with Salmonella in slaughterhouse (Breytenbach, 2004).

Techniques used for the detection of Salmonella in chickens mostly suffer from being either time-consuming, labor intensive, or expensive. The application of the PCR is one approach for the rapid and effective detection and identification of Salmonella. Application of PCR for detection of SE was carried out by many authers: Oliveira et al. (2002) developed a PCR assay for the generic detection of SE in materials collected from chicken in the field and they found that PCR assay detected more positive field samples than the standard microbiological techniques and results were ready in $48 \mathrm{hrs}$ instead of 7 days, Meran Sleim (2003) compared between bacteriological methods and PCR for diagnosis of SE, and revealed that the bacteriological methods failed to detect the shedding of SE from cloacal swabs collected $8 \mathrm{hrs}$ post infection and incubated for $8 \mathrm{hrs}$ at $37 \mathrm{C}^{0}$, while PCR succeeded in detection of Salmonella in these incubated samples. Also, Allgayer et al. (2008) tested 280 birds samples by PCR using a pair of primers that amplify a 284 base pair fragment of SE then they retested the PCR-positive samples by standard microbiological techniques and discovered that $13 \%$ of the samples were positive by PCR, but negative by microbiological techniques emphasizing the sensitivity and specificity of PCR. Shita (2009) examined 6 serologically identified SE serotypes recovered from feed and litter by PCR and the all of them were positive (100\%). Ayoub (2010) found that the overall occurrence of Salmonella recovered from chicken cloacal swabs and environmental samples under experiment was $6.66 \%$ by PCR and $5.71 \%$ by conventional bacteriological method.

Beside the zoonotic potential of SE transmitted through poultry, the main aim of this study was to evaluate PCR as a rapid accurate diagnostic tool applied for detection of SE in both chicken and human.

\section{MATERIALS and METHODS}

\section{- Collection of samples for surveying Salmonella:}

110 chicken samples were collected randomly from naturally infected farms in Al-Rahmania district in Behera Province, Egypt. Birds suffered from mottled liver with yellowish discoloration, distended gallbladder, slight air sacculitis, congested lungs and enlarged spleens. Liver, heart, spleen and cloacal swabs from 
chickens were sampled. In addition, 50 human stool samples were collected from persons suffering from pyrexial illness with diarrhea and vomiting for several days hospitalized in the surrounding areas of examined poultry farms.

- Isolation of Salmonella was carried out according to Waltman et al. (1998).

- Identification of Salmonella isolates was carried out in the Serology Unit in (Animal Health Research Institute, Dokki Giza).

- Detection of SE by PCR was carried out according to Soumet et al. (1999):

The primers were synthesized and supplied by Pharmacia Co. Biolegio BV and were selected to specifically amplify the SefA gene of SE. Two primers were needed:

Upstream primer with a sequence of 5/AGG TTC AGG CAG GGG TTA CT 3 .

Downstream primer with a sequence of: 5 / GGG AGA TTT AGG GTT TCT TG3 /.

\section{RESULTS}

Table 1: Percentage of isolation of Salmonella from different samples under investigation.

\begin{tabular}{|l|c|c|c|}
\hline \multirow{2}{*}{ Examined samples } & No. of examined samples & \multicolumn{2}{|c|}{ Positive samples } \\
\cline { 3 - 4 } & & No. & $\%$ \\
\hline Chickens & 110 & 4 & 3.63 \\
\hline Human & 50 & 2 & 4 \\
\hline Total & 160 & 6 & 3.75 \\
\hline
\end{tabular}

Table 2: Serological identification of Salmonella isolates.

\begin{tabular}{|c|c|c|c|c|c|}
\hline \multirow{3}{*}{$\begin{array}{l}\text { No of } \\
\text { identified } \\
\text { isolates }\end{array}$} & \multicolumn{3}{|c|}{ Antigenic structure } & \multirow[t]{3}{*}{ Group } & \multirow{3}{*}{$\begin{array}{l}\text { Salmonella } \\
\text { serotype }\end{array}$} \\
\hline & \multirow{2}{*}{$\begin{array}{c}\text { Somatic }(\mathrm{O}) \\
\text { antigen }\end{array}$} & \multicolumn{2}{|c|}{$\begin{array}{l}\text { Flageller }(\mathrm{H}) \\
\text { antigen }\end{array}$} & & \\
\hline & & Phase I & Phase II & & \\
\hline 4 & $1,9,12$ & g.m & - & O:9 (D1) & S. Enteritidis \\
\hline
\end{tabular}


Table 3: Results of examination of positive samples by PCR using SefA gene of $S$. Enteritidis:

\begin{tabular}{|l|c|c|c|}
\hline & No of examined samples & Positive & $\%$ \\
\hline Chickens & 4 & 3 & 75 \\
\hline Human contacts & 2 & 1 & 50 \\
\hline Total & 6 & 4 & 6.66 \\
\hline
\end{tabular}

Photo: Sowing the ethidium bromide stained gel of the PCR products of isolates of $S$. Enteritidis.

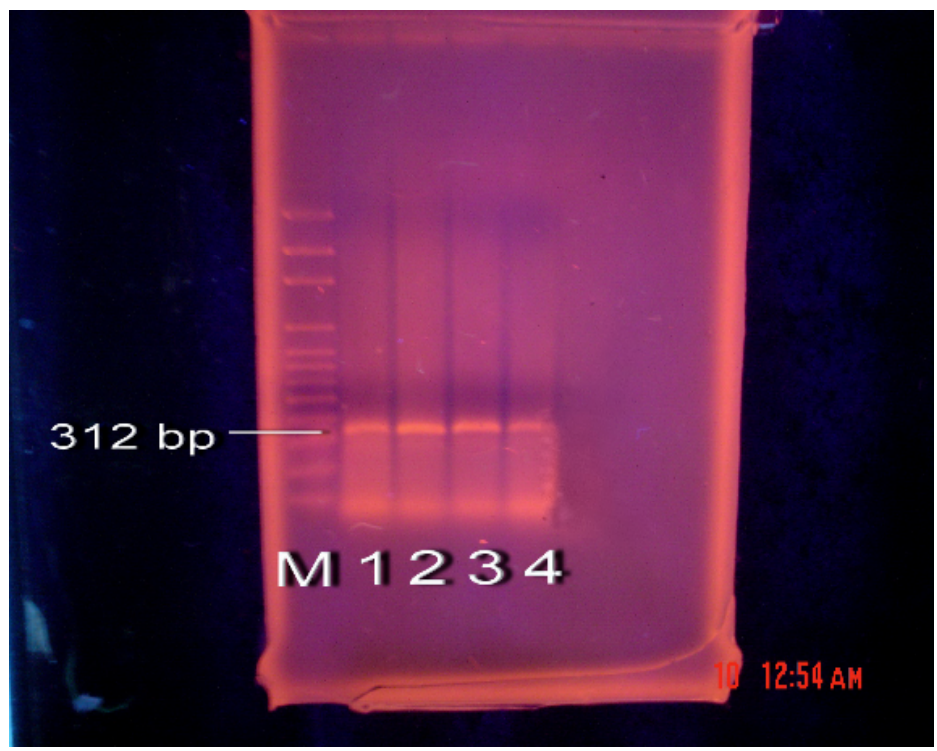

Lane M: 100 bp DNA ladder, Lanes (1- 4): Positive isolates for S. Enteritidis

Lanes 1, 2, and 3 are isolates from chickens, lane 4 human isolate

\section{DISCUSSION}

Poultry industry plays an important role in offering cheap source of animal protein for human beings in Egypt where prices of red meat, milk products and other sources of animal protein reached very high levels. At the same time, poultry can be considered a hazardous source 
of human infection by many zoonotic diseases including SE infection. Accurate and rapid diagnosis is the corner stone in controlling such zoonosis.

The percentage of isolation of Salmonella from 110 chicken samples was tabulated in Table 1 that clarified that the total percentage of Salmonella isolated from organs and cloacal swabs was $3.63 \%$. This result was found in agreement with that reported by Kim et al. (2007); Trawiska et al. (2008) who isolated Salmonella from broiler chicken farms. The recorded isolation rate of Salmonella in the current study was higher that recorded by Hanson et al. (2002) (2.25\%), while it was lower than that reported by Jafari et al. (2007) (5.8 \%) and Ayoub (2010) (5.62 $\%)$. The isolation of Salmonella from chickens could be an indication of low degree of hygiene and biosecurity in the broiler farms under investigation, state of health, state of immunity and medication during sample collection. Moreover, the variation in isolation rates may be attributed to various methods of isolation and purification. Also, the data presented in Table 1 showed that the percentage of isolation of Salmonella from 50 human stool samples was $4 \%$. This result was higher than that obtained by Schmid et al. (2008) (2.7\%). On contrary, it was lower than that recorded by Heir (2002) (32\%), Arshadab et al. (2007) (9.9\%), Toyofuku (2008) (7 \%) and Arnold et al. (2010) (14\%).

The biochemically identified Salmonella isolates were subjected to serological identification using polyvalent and monovalent $(\mathrm{O})$ and (H) Salmonella antisera. The results of serological identification illustrated in Table 2 were 3 isolates proved to be SE isolated from chicken and one isolate proved to be SE isolated from human. This finding was in agreement with Sobel et al. (2000) who proved that the percentage of Salmonella outbreaks that were caused by SE increased from $47 \%$ to $55 \%$, and SE was the most common cause of all food borne disease outbreaks in the United States during this same period. Although some serotypes, such as $S$. typhimurium, were common in many different animal species, a number of Salmonella serotypes have specific animal reservoirs that are thought to contribute to disease in humans. This might support the higher recovery of SE among the whole isolates.

The present study highlighted that SE was most prevalent Salmonella serotype affects human with history of contact with poultry. It was agreed with the study of Al-Nakhli et al. (1999); Carli et al. (2001); Abd El-Haleem (2003); Adam (2006); El-Zenky et al. (2007); Shita (2009) and Ayoub, (2010). 
Because Salmonella has veterinary and public health hazards, there is an increasing need for rapid and accurate tool for detection of Salmonella infection in both chicken and human. PCR is more sensitive than conventional methods due to its increased sensitivity compared to culture techniques. Also, PCR has many advantages as it is highly specific and sensitive, results can be obtained within 24 -30 hrs period which could be of critical importance for the food industry (Meran Sleim, 2003; Shita, 2009; Ayoub, 2010). So, depending on above mentioned facts, a PCR based detection assay was employed in this study for detection of SE. From the whole 6 revealed Salmonella isolates, $\mathrm{SE}$ was represented in 4 out of 6 isolates at a percentage of 6.66 $\%$ as shown in Table 3.

The photo displayed PCR products using SefA gene of SE on agarose gel stained with ethidium bromide. The DNA bands of $312 \mathrm{bp}$ were an indication for the presence of SE. Lanes number 1, 2, and 3 represented isolates from chickens while lane number 4 represented human isolate. This result agreed with the finding of Oliveira et al. (2002); Eyigor and Carli (2003); Allgayer et al. (2008) who found that 312 bp notified the presence of SE DNA. These results indicated that PCR technique is more accurate, rapid and sensitive test than culture method. This result supported by that reported by Soumet et al. (1999); Waage et al. (1999); Allgayer et al. (2008).

The obtained results from this study confirmed the role of chicken in transmitting SE to human contacts that represented a real problem needs to be more investigated and effective control measures to be established in order to prevent human infection.

\section{REFERENCES}

Abd El-Haleem, Y.F. (2003): Some epidemiological studies on Salmonella in poultry farms. Ph.D. Thesis. Fac. Vet. Med. Zagazig Univ.

Adam, A.F.H. (2006): Studies on Salmonella infection in chickens in Libya. M.V.Sc. Thesis, Fac. Vet. Med., Alex. Univ., Egypt.

Al-Zenki, S.; Al-Nasser, A.; Al-Safar, A.; Alomirah, H.; Al-Haddad, A.; and Aarestrup, F.M. (2007): Prevalence and antibiotic resistance of Salmonella isolated from a poultry farm and processing plant environment in the State of Kuwait. Foodborne Pathog. Dis.; 4 (3): 367-73. 
Al-Nakhli, H.M.; Al-Ogaily, Z.H. and Nassar, T.J. (1999): Representative Salmonella serovars isolated from poultry and poultry environments in Saudi Arabia. Official International Des. Epizooties, 18, (3): 700-709.

Allgayer, M.C.; Lima-Rosa, C.A.V.; Weimer, T.A.C.; Rodenbusch, R.; Pereira, R.A.A.; Streck, F.; Oliveira, S.D. and Canal, C.W. (2008): Molecular diagnosis of Salmonella species in captive psittacine birds. Vet. Rec. 162: 816-819.

Arshadab, M.M.; Wilkins, M.J.; Downes, F.P.; Rahbard, M.H.; Erskine, R.J.; Boulton, M.L. and Saeed, A.M. (2007): A registery-based stydy on the association between human samonellosis and routinely collected parameters in Michigan, 1995-2001. Foodborne Pathog. Dis., 4 (1): 16-25.

Arnold, ME.; Papadopoulou, C.; Davies, RH.; Carrique-Mas, JJ. and Hoinville, LJ. (2010): Estimation of Salmonella prevalence in UK egg-laying holdings. Prev Vet Med. 1;94 (3-4): 306-9.

Ayoub, M.A.M. (2010): Epidemiological Studies on Salmonella in some poultry farms. PhD. thesis, Fac. Vet. Med. Alex. Univ.

Breytenbach, J.H. (2004): Salmonella Control in Poultry. Intervet International B.V.Sc.

Carli, K.T.; Eyigor, A. and Caner, V. (2001): Prevalence of Salmonella serovars in chickens in Turkey. J. Food Prot. 64(11): 1832-5.

Eyigor, A. and Carli, K.T. (2003): Rapid detection of Salmonella from poultry by real-time polymerase chain reaction with fluorescent hybridization probes. Avian Dis. 47 (2): 380-6.

Gast, R.K.; Robert, E.P.Jr. and Peter, S.H. (1997): Applied tests for specific yolk antibodies to predict contamination by S.enteritidis in eggs from experimentally infected laying hens. Avian Dis., 41: 195-202.

Hanson, R.; Kaneene, J.B.; Padungtod, P.; Hirokawa, K. and Zeno, C. (2002): Prevalence of Salmonella and E. coli, and their resistance to antimicrobial agents, in farming communities in northern Thailand. Southeast Asian J. Trop Med. Public Health. 33 Suppl 3: 120-6.

Heir, E.; Lindstedt, B.A. and Nygard, I. (2002): Molecular epidemiology of Salmonella Typhimurium isolates from human sporadic and outbreak cases. Epidemiol. Infect., 128: 373-382. 
Jafari, R.A.; Fazlara, A. and Govahi, M. (2007): An investigation into Salmonella and fecal coliform contamination of drinking water in broiler farms in Iran. International Journal of Poultry Science 5 (5): 491-493.

Kim, 1.A.; Lee, Y.J.; Kang, M.S.; Kwag, S.I. and Cho, J.K. (2007): Dissemination and tracking of Salmonella spp. in integrated broiler operation. J. Vet. Sci., 8(2), 155-161.

Mahon, J.; Murphy, C.K.; Jones, P.W. and Barrow, P.A. (1994): Comparison of multiplex PCR and standard bacteriological methods of detecting Salmonella on chicken skin. lett. Appl. Microbiol., 19 (3): 169-172.

Olivera, S.D.; Santos, L.R.; Schuch, D.M.; Silva, A.B.; Sale, C.T. and Canal, C.W. (2002): Detection and identification of Salmonella from chicken related samples by PCR. Vet. Microbiol., 87(1): 25-35

Meran, Sleim (2003): Epidemiological studies on Salmonella in poultry. Ph.D. Thesis. Fac. Vet. Med. Alex. Univ., Egypt.

Schmid, H. (2008): Outbreak of Salmonella enteric serovar typhimurium in june 2008, implications for production and control of meat. Eurosurveillance, 13 (44).

Shita, H.M.A. (2009): Epidemiological studies on some pathogenic bacteria inside poultry farms. M.V.Sc. Thesis (Animal Hygiene), Fac. Vet. Med., Alex. Univ., Egypt.

Sobel, J.; Hirshfeld, AB.; McTigue, K.; Burnett, CL.; Altekruse, S.; Brenner, F.; Malcolm, G.; Mottice, SL.; Nichols, CR. and Swerdlow, DL. (2000): The pandemic of Salmonella enteritidis phage type 4 reaches Utah: a complex investigation confirms the need for continuing rigorous control measures. Epidemiol Infect. 125 (1): 1-8.

Soumet, C.; Erme, G.; Rose, V.; Rose, N.; Drouin, P.; Salvat, G. and Colin, P. (1999): Identification by a multiplex PCR-based assay of Salmonella Typhimurium and Salmonella Enteritidis strains from environmental swabs of poultry houses. Letters in Applied Microbiology, 29: 1-6.

Toyofuku, H. (2008): Epidemiological data on food poisoning in Japan focused on Salmonella, 1998-2004. Food Addit.Contam. Part A Chem. Anal. Control Expo.Risk Assess. 25 (9): 1058-66. 
Trawi ska, B.; Saba, L.; Leszek, W.L. and Dêbek, N. (2008): Evaluating of Salmonella rods incidence in poultry in the Lublin province over the years 2001-2005. Ann Agric Environ Med. 15: 131-134.

Waage, A.S.; Vardund, T.; Und, V. and Kapperud, G. (1999): Detection of low numbers of Salmonella in environmental water, sewage and food samples by a nested polymerase chain reaction assay. Journal of Applied Microbiology, 87: 418-428.

Waltman, W.D.; Gast, R.K. and Mallinson, E.T. (1998): Salmonellosis. In: A laboratory manual for the isolation and identification of avian pathogens. $4^{\text {th }}$ ed., Swayne, D.E.; Glisson, J.R.; Jackwood, M.W.; Pearson, J.E. and Reed, W.M., Amer. Assoc. Avian Pathol., Pennsylvania Univ. New Bolton Center, Kennett Square, PA. 19348-1692. 